
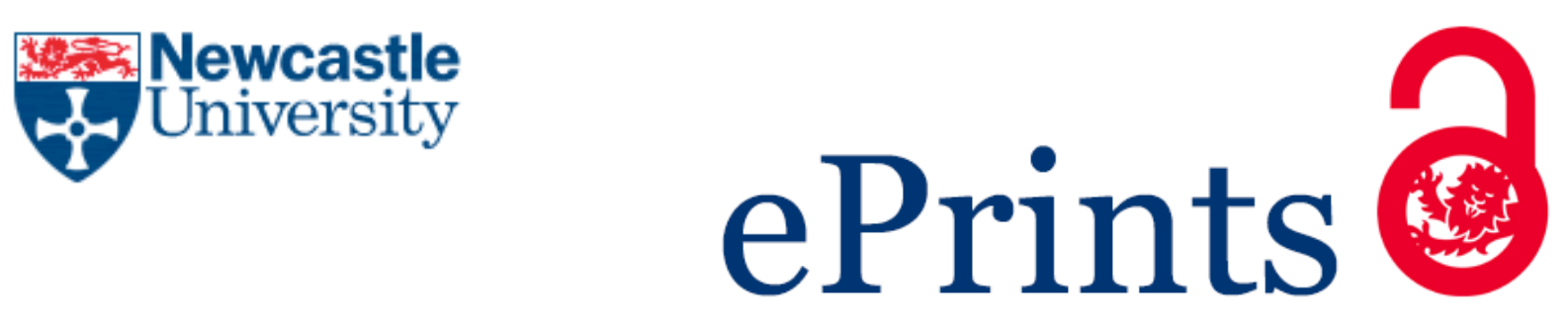

Fu G, Horrocks L, Winne S.

Exploring impacts of Climate Change on UK's ICT Infrastructure.

Infrastructure Asset Management 2016, 3(1), 42-52

\title{
Copyright:
}

(C) ICE Publishing. All rights reserved.

DOI link to article:

http://dx.doi.org/10.1680/jinam.15.00002

Date deposited:

$01 / 04 / 2016$

Embargo release date:

01 March 2016 


\section{Exploring impacts of climate change on UK's ICT infrastructure}

1 Gaihua Fu BSC, PhD

Centre for Earth Systems Engineering Research, School of Civil Engineering and Geosciences, Newcastle University, Newcastle upon Tyne, UK (corresponding author: gaihua.fu@ncl.ac.uk)
2 Lisa Horrocks $B A, P h D$

Principal Consultant, Ricardo Energy \& Environment, Harwell, Didcot, Oxfordshire, UK

3 Sarah Winne BA, MSC

Senior Consultant, Ricardo Energy \& Environment, Harwell, Didcot, Oxfordshire, UK
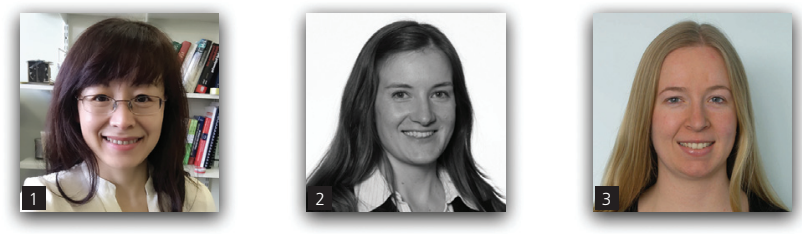

Information and communication technology (ICT) infrastructure plays a critical role in many aspects of the society. While ICTs contribute to climate-related responses and adaptive practices, much less is known about the impacts that climate change may have on ICT itself. Drawing on knowledge in the literature and findings elicited from industrial workshop conversations and case studies, this paper attempts to provide a review of available evidence of climate impacts on the UK's ICT infrastructure. This research shows that, although ICTs are resilient to climate impacts, in part due to the rapid refresh rate of equipment, ICTs are vulnerable to a number of future climate risks. The criticality of ICTs to other infrastructure sectors implies that any disruption to ICTs could result in multisectoral cascade failures. This paper also explores the potential for strategies to adapt ICTs to be more resilient to extreme weather and changes in climate, discusses some of the opportunities that climate change may offer and identifies some areas for further research.

\section{Introduction}

Information and communication technology (ICT) infrastructure is critically important to the society. An ICT system comprises integrated networks, systems and components that enable the transmission, receipt, capture, storage and manipulation of information by users on and across electronic devices. ICT is a relatively new but rapidly developing infrastructure sector. As reported by the International Telecommunication Union (ITU, 2014), the UK is one of the world's largest ICT markets. The UK's ICT industry is worth $£ 58$ billion annually (UK Trade \& Investment, 2014), and is ranked as the fifth in 2014 globally in terms of development (ITU, 2014). There is a continued growth in the uptake and spread of ICTs (Ofcom, 2014).

ICTs are central to the business-as-usual operation of every industry and sector, and the contemporary world is highly reliant on ICTs for social and leisure purposes, as well as work. The growing demand for ICTs assumes that ICTs are always available. This makes any disruptions to ICT service provision unacceptable, from both work and social perspectives (Nogueira et al., 2014; Sterbenz et al., 2010). With the high value of transaction rates per minute, unplanned ICT downtime represents a significant financial risk to business (Clemente, 2013). From a business continuity perspective, it is likely that these risks are understood and planned for by larger companies. However small to medium-sized companies and individual consumers may not have systems in place to cope with unplanned disruption to their ICT systems (Baglee et al., 2012).

Among other threats (e.g. terrorists and cyberattacks), ICTs are potentially vulnerable to a number of weather- and climate-based disruptions (Chołda et al., 2007; Rak, 2015). Risks from the changing climate are of particular concern (Ospina et al., 2014). The 2009 UK Climate Projections (UKCP09) identified the main climate change variables as temperature, precipitation, relative humidity and clouds and extremes of temperature and precipitation (Jenkins et al., 2009; Murphy et al., 2009). Extreme weather leading to floods or heatwaves is a particular concern. The changing climate is expected to bring increases in both the frequency and the severity of this kind of weather.

Changing climate already starts to cost the UK's ICT sector. The chief executive officer of the British telecommunication company BT admitted that climate change is affecting his company, and he revealed that extreme weather in the form of flooding and high 
winds has hit BT's operations (Adams et al., 2014). The need to understand climate risks to ICTs is acknowledged by the UK's National Adaptation Programme (Defra, 2009, 2013; Engineering the Future, 2011), which recognised the priority to develop a better understanding of climate risks to ICT service delivery and their interdependencies with other sectors.

Research and studies to date mostly focus on the potential of ICTs in tackling climate change impacts - that is, ICTs serve as enablers of innovative approaches to mitigate, monitor and adapt to climate change impacts (Kelly and Adolph, 2008; Ospina and Heeks, 2010). There is a limited amount of evidence about the specific impacts that climate change may have on ICT infrastructure itself, and published analysis is extremely rare, as recognised by Rak (2015) and Ospina et al. (2014). Given the pace of development and change in ICTs, new risks can emerge relatively quickly. For example the increasing use of remotely held data and applications offers simultaneously greater resilience (from the local disruption of a single device failure) and greater potential risk (if network connectivity fails). These trends bring both challenges and opportunities for managing and planning resilience in ICTs.

This paper explores the effects of climate change on the UK's ICT sector. It aims to raise awareness of the need to design and implement strategies for the sector to better prepare for, respond to and adjust to the impacts of short- and long-term climatic changes. This paper gives an overview of the impacts, opportunities and challenges posed by climate change to sector stakeholders. The study draws on a very limited literature, which is substantially augmented by expert elicitation from ICT sector expert workshop discussions and case studies. This paper presents the key findings of the research, including the following: $(a)$ The UK's ICT sector is inherently resilient and adaptable to climate impacts to some extent, although this is not necessarily the case at the level of an individual end user. (b) Providers and consumers of ICTs will nevertheless need to consider adaptation, because of the UK's increasing dependence on ICTs and increases in extreme weather events. (c) ICTs are vulnerable to a number of current and future climate risks. (d) Climate impacts on ICTs can have considerable cross-sectoral implications for infrastructure and business. This paper also explores the potential for strategies to adapt ICTs to be more resilient to extreme weather and changes in climate, and identifies some of the opportunities that these changes may offer. Finally, this paper reflects on the gaps in the literature and identifies some priorities for further research.

\section{Identifying climate impacts on ICTs: previous research and this study's method}

Given insufficient evidence and understanding of climate impacts on ICTs, this study attempts to identify and synthesise current knowledge and experience to provide an assessment of climate impact risks in the UK's ICT sector. This study draws its findings from the latest research outcomes emerging in the literature as well as the outcomes of an ICT sector expert workshop, with the aim to provide a snapshot of the current state of practices in the area and lay a foundation for further research.

The authors have looked at a broad range of potential sources for existing works and publications on climate resilience of ICTs, including those from the academe, government, environmental agencies and business organisations. They found that the literature is rich in studies on scenarios of isolated random failures of ICT components being the result of software errors or physical faults (Chołda et al., 2007; Sterbenz et al., 2010), but the amount of published literature on ICT resilience with respect to weather- and climate-based disruptions is small and limited, as recognised by Nogueira et al. (2014) and Rak (2015). Although the linkage between ICTs and climate impacts is gaining increasing attention, the research to date focuses mostly on the potential of ICTs in tackling climate change impacts - for example, how ICTs contribute to the abatement of carbon dioxide emissions, energy efficiency, monitoring of climate-related patterns and events and implementation of adaptive practices (Eakin et al., 2015; Kelly and Adolph, 2008; Ospina and Heeks, 2010; Upadhyay and Bijalwan, 2015) - and much less is known about the impacts of climate changes on ICTs and the adaptive strategies that the ICT sector itself could adopt to better prepare for, respond to and adjust to more frequent and intense climatic impacts (Ospina et al., 2014).

The importance of understanding climate impacts on ICTs has just started to attract attention in recent years, and the need to investigate these impacts has risen up the agenda of some international organisations, governments and industry sectors. For example, a specialised agency of UN, the ITU, has taken an action to collaborate with global communities to address the climate changes on ICTs. A working paper has been produced to give an overview of the impacts, opportunities and challenges posed by climate change to sector stakeholders (Ospina et al., 2014). The study identifies existent and emerging adaptive measures and provides suggested actions to strengthen the ICT sector's approach to adaptation. The study performed by Adams et al. (2014) analyses the impacts of climate changes on ICTs and data centre services. The study highlights a number of suggested adaptation options from around the world, including some case studies of early implementation actions by ICT companies to build resilience.

Some studies have been carried out to investigate the climate impacts on ICTs in specific countries and regions (Horrocks et al., 2010; Paulson, 2011; Steeves and Surminski, 2014; Wong and Schuchard, 2011). In the paper of Jacob et al. (2011), an assessment is carried out to analyse the climate impacts in the New York State's telecommunications sector, and suggests various technical and strategic adaptation options. A unique contribution of this study is that it explores the impacts on vulnerable communities, such as those in rural areas or the lower-income, elderly or disabled populations. It also demonstrates potential climate impacts through a case study of historical extreme winter storms. An independent study commissioned by the Australian government is reported by Maunsell Australian Pty (2008). This 
study reviews the impacts of climate changes on ICT infrastructure under seven different climate scenarios, for the 2030s, 2070s and 2100 s. The report adopts an economic lens, describing the impacts in terms of their effect on operational and capital expenditures.

The UK is one of countries that have a significant interest in studying climate impacts on ICTs (Baglee et al., 2012; Carbon Disclosure Project, 2012; Defra, 2013; Engineering the Future, 2011; Horrocks et al., 2010). Of particular interest are the findings of an ICT expert workshop, on which many results of this study are based. The workshop was undertaken as part of a UK government programme for adapting national infrastructure (NI) and is considered as one of the most comprehensive studies of its kind on climate risks in the ICT sector, as recognised by Adams et al. (2014). The description of the workshop is given in the Supplementary Material, and the reader is referred to the papers of Baglee et al. (2012) and Horrocks et al. (2010) for further details of the workshop. The workshop engaged experts working in the sector, from the academia, policymaking bodies/the government, regulatory/standardisation bodies, technical fields/ networks, the services/distribution sector, and practitioners in related sectors such as rail. Appropriate climate scenarios (based on UKCP09) were developed to form the basis of discussion, structured around the following key questions.

- What are the future developments in ICT over the next 20 and 50 years or for longer term? What are the implications for technical standards?

- What challenges/opportunities do these present? For operations, standards, supply chain (in particular ownership) and reputation?

- What risks (in general) will become present and/or increase? What risks related to weather/climate will emerge or reduce?

- How is resilience currently built into ICT infrastructure (and plans for the future)?

- How can resilience, in particular climate resilience, be increased and barriers be overcome? What are the business/ economic challenges, and opportunities, that this will generate?

- How does the regulatory regime enable/inhibit resilience?

The authors have explored the outcomes of the workshop to investigate potential risks and possible solutions in the context of the long-term future for the ICT sector in the UK. The results were further augmented and supported with evidences that had been elicited from published literature. The key findings of this study are presented in the following sections, with 'Impacts and risks of climate changes on the UK's ICTs' focusing on the impacts of climate change on ICTs in general and 'Risk from cross-sectoral interdependencies' on the risk from cross-sectoral interdependencies.

\section{Impacts and risks of climate changes on the UK's ICTs}

This study suggests that the UK ICT infrastructure is inherently resilient to climate change impacts. There are a few reasons for this. Firstly, the majority of the components and devices typically used in the UK are also used in other parts of the world that already experience environmental conditions beyond the range of UKCP09. Provided that such components are appropriately installed and maintained, they should accommodate the climate conditions anticipated in the UK this century. Secondly, the lifetime of many components is short compared to the timescales of climate change, so there is time for adaptation into new technologies to keep pace with climate change.

However, vulnerabilities do exist. The challenge is rooted not in ICT devices themselves but in the environmental conditions that surround them and the impact of weather events. For example devices located below ground (such as cabling) are potentially vulnerable to flooding from rivers, coastal storm surges and extreme rainfall, rising water tables, water ingress (particularly during times of snowmelt or flooding), subsidence caused by drought or flooding and consequential risks arising from damage to other structures (such as bridges) that support ICTs (Adams et al., 2014). Above ground, structures (such as masts, antennae, switch boxes, aerials, overhead wires and cables) are at risk from precipitation (water ingress), wind, snow (weight), unstable ground conditions (flooding, subsidence) and changes in humidity (Horrocks et al., 2010). High humidity can lead to condensation and risk of water ingress and short-circuiting of equipment (Engineering the Future, 2011). The serviceable lifespan of some components may be affected by increased environmental stress (high winds, temperatures).

These risks will evolve with changing climate. Extreme weather events may increase in frequency or severity in future. There are a wide variety of ways in which weather and climate changes can affect ICT infrastructure. Table 1 summarises the expected changes in climate under the Intergovernmental Panel on Climate Change (IPCC) medium emissions scenario by the 2080s (Murphy et al., 2009), as well as the potential impacts of these changes on the UK's ICTs as identified during this study. The consequences of these climate impacts and the scale at which the impact might be felt will be discussed.

\section{Daily precipitation}

Increases in extreme daily precipitation, including very wet days, may have several negative effects on ICT infrastructure, including increasing the risk of flooding to low-lying infrastructure and underground facilities. It may result in increased erosion and flood damage to transport structures that could expose cables. Precipitation changes (rate of rainfall, size of raindrop and whether precipitation falls as rain or snow) can affect the quality of wireless services through impacts on wave propagation (Sterbenz et al., 2013).

In the UK, a significant proportion of point-to-point data traffic is over radio links. The majority of these links are engineered to $99 \cdot 99 \%$ average annual availability, and so they fail for about $50 \mathrm{~min}$ a year in moderate rain rates of about $25 \mathrm{~mm} / \mathrm{h}$ (Bacon, 2012; Paulson, 2010, 2011). There are clear increasing trends in the incidence of these rain rates. It is likely that outage rates are 


\begin{tabular}{|c|c|c|c|c|c|c|c|}
\hline \multicolumn{2}{|r|}{ Climate impacts on ICTs } & \multicolumn{6}{|c|}{ Potential consequences } \\
\hline Climate factor & Potential impact & $\begin{array}{l}\text { Degradation of } \\
\text { infrastructure }\end{array}$ & $\begin{array}{l}\text { Availability } \\
\text { of services }\end{array}$ & $\begin{array}{l}\text { Quality } \\
\text { of } \\
\text { services }\end{array}$ & $\begin{array}{l}\text { Repair } \\
\text { and } \\
\text { recovery }\end{array}$ & $\begin{array}{l}\text { Business } \\
\text { costs }\end{array}$ & $\begin{array}{l}\text { Health } \\
\text { and } \\
\text { safety }\end{array}$ \\
\hline \multirow{2}{*}{$\begin{array}{l}\text { Increase in } \\
\text { maximum } \\
\text { temperatures } \\
\text { (and higher } \\
\text { frequency of } \\
\text { 'very hot' days) }\end{array}$} & $\begin{array}{l}\text { Increased risk of overheating in data } \\
\text { centres, exchanges, base stations } \\
\text { and so on }\end{array}$ & & 约 & & & Љ & Љ \\
\hline & $\begin{array}{l}\text { Increased heat-related health and } \\
\text { safety risks to exposed workers (e.g. } \\
\text { maintenance engineers, drivers and } \\
\text { staff in exchanges) }\end{array}$ & & & & ת & & ת \\
\hline \multirow[t]{2}{*}{$\begin{array}{l}\text { Increase in } \\
\text { average } \\
\text { temperatures }\end{array}$} & $\begin{array}{l}\text { Location/density of wireless masts } \\
\text { may become suboptimal since } \\
\text { wireless transmission is dependent } \\
\text { on temperature (refractive index) }\end{array}$ & & 凡 & \ & & ת & \\
\hline & $\begin{array}{l}\text { Impact on quality of radio-frequency } \\
\text { propagation if vegetation type } \\
\text { changes in response to climate }\end{array}$ & & & \ & & & \\
\hline \multirow{3}{*}{$\begin{array}{l}\text { Increase in } \\
\text { minimum } \\
\text { temperatures } \\
\text { (fewer frost days } \\
\text { and less } \\
\text { snowfall) }\end{array}$} & $\begin{array}{l}\text { Reduced costs of space heating in } \\
\text { assets (data centres, exchanges and } \\
\text { so on) in winter }\end{array}$ & & & & & 仓े & \\
\hline & $\begin{array}{l}\text { Reduced impacts of snowfall on } \\
\text { masts, antennae and so on, } \\
\text { requiring less maintenance }\end{array}$ & 仓 & 仓 & & & 仓े & 仓 \\
\hline & $\begin{array}{l}\text { Less frequent requirement to cope } \\
\text { with snowmelt water surge (flood) } \\
\text { problems }\end{array}$ & 仓 & 仓े & & $\widehat{\imath}$ & 仓 & 仓े \\
\hline \multirow{5}{*}{$\begin{array}{l}\text { Increase in } \\
\text { extreme daily } \\
\text { precipitation in } \\
\text { winter (and } \\
\text { higher frequency } \\
\text { of 'very wet' } \\
\text { days) }\end{array}$} & $\begin{array}{l}\text { Increased risk of flooding of low- } \\
\text { lying infrastructure, access holes and } \\
\text { underground facilities }\end{array}$ & ת & \ & & & ת & ת \\
\hline & $\begin{array}{l}\text { Increased erosion or flood damage } \\
\text { to transport structures, which may } \\
\text { expose cables/trunk routes }\end{array}$ & ת & \ & & & ת & \\
\hline & $\begin{array}{l}\text { Reduced quality of wireless service } \\
\text { with higher rainfall rates }\end{array}$ & & & \ & & & \\
\hline & $\begin{array}{l}\text { Increased flood risk to assets located } \\
\text { in flood plains or urban } \\
\text { environments - for example data } \\
\text { centres }\end{array}$ & & \ & & \ & $\sqrt{3}$ & \\
\hline & $\begin{array}{l}\text { Increasing difficulty to repair faults } \\
\text { and restore service }\end{array}$ & & \ & \ & 凤 & $\sqrt{3}$ & 凤 \\
\hline $\begin{array}{l}\text { Decrease in daily } \\
\text { precipitation in } \\
\text { summer }\end{array}$ & $\begin{array}{l}\text { Increased risk of subsidence, } \\
\text { reduced stability of foundations and } \\
\text { tower structures }\end{array}$ & Л & & & & ת & \\
\hline
\end{tabular}

Updated from Horrocks et al. (2010)

$\sqrt{ }$, a potential negative effect; $\uparrow$, a potential positive effect; $\hat{\imath}$, the direction of the effect is uncertain

Table 1. Potential climate impacts on ICTs (continued on next page) 


\begin{tabular}{|c|c|c|c|c|c|c|c|}
\hline \multicolumn{2}{|r|}{ Climate impacts on ICTs } & \multicolumn{6}{|c|}{ Potential consequences } \\
\hline Climate factor & Potential impact & $\begin{array}{l}\text { Degradation of } \\
\text { infrastructure }\end{array}$ & $\begin{array}{l}\text { Availability } \\
\text { of services }\end{array}$ & $\begin{array}{l}\text { Quality } \\
\text { of } \\
\text { services }\end{array}$ & $\begin{array}{l}\text { Repair } \\
\text { and } \\
\text { recovery }\end{array}$ & $\begin{array}{l}\text { Business } \\
\text { costs }\end{array}$ & $\begin{array}{l}\text { Health } \\
\text { and } \\
\text { safety }\end{array}$ \\
\hline \multirow[t]{2}{*}{$\begin{array}{l}\text { Changes in } \\
\text { storminess and } \\
\text { wind }\end{array}$} & $\begin{array}{l}\text { Changes in storm/wind-loading } \\
\text { damage to all above-ground } \\
\text { transmission infrastructure }\end{array}$ & 众 & 众 & & 众 & 众 & \\
\hline & $\begin{array}{l}\text { Lightning strike damage to } \\
\text { transmitters }\end{array}$ & 众 & 众 & 众 & & 众 & \\
\hline \multirow{3}{*}{$\begin{array}{l}\text { Rising sea levels } \\
\text { (particularly in } \\
\text { south-east and } \\
\text { eastern England) } \\
\text { and increase in } \\
\text { storm surges }\end{array}$} & $\begin{array}{l}\text { Increased saline corrosion of coastal } \\
\text { infrastructure (broadcasting towers } \\
\text { and so on) }\end{array}$ & \ู & & & & 约 & \\
\hline & $\begin{array}{l}\text { Increased risk of coastal erosion and } \\
\text { coastal flooding of infrastructure in } \\
\text { vulnerable areas }\end{array}$ & \ู & ת & & \ู & 约 & \勺 \\
\hline & $\begin{array}{l}\text { Potential change in reference datum } \\
\text { for some telecommunication/satellite } \\
\text { transmission calculations }\end{array}$ & & & ת & & & \\
\hline \multirow{2}{*}{$\begin{array}{l}\text { Changes in } \\
\text { (absolute) } \\
\text { humidity }\end{array}$} & Changes in corrosion rates & 企 & & & & 企 & \\
\hline & $\begin{array}{l}\text { Changes in requirements for } \\
\text { dehumidification to maintain internal } \\
\text { environments within tolerance } \\
\text { ranges of system devices }\end{array}$ & & & & & $\hat{\imath}$ & \\
\hline
\end{tabular}

Table 1. Continued

increasing dramatically in the UK - for example, doubling or tripling each decade (Paulson and Al-Mreri, 2011). The effect of this is likely to be minor as outages tend to be short - for example, less than a minute or two - and effect services are over a small area. The exceptions are at the edges of networks (e.g. links to Scottish islands) and for multihop links where outage by one link effects all downstream nodes.

\section{Extreme temperature}

Heatwaves increase the risk of overheating in older buildings (such as Victorian exchanges) and lead to increased demand for cooling in data centres (Adams et al., 2014; Wong and Schuchard, 2011). Extreme temperatures bring potential health and safety issues for outdoor or exposed workers (Wong and Schuchard, 2011). Increases in temperature can limit the range of wireless signals, particularly at extremely high temperatures (Adams et al., 2014). The failure rate of an electrical component increases exponentially with temperature (Mishra et al., 2004).

\section{Windstorms}

Severe windstorms around the UK have become more frequent in the past few decades (although not above that seen in the 1920s) (Murphy et al., 2009). High winds and storms have the potential to knock down masts and damage above-ground assets, including the power lines supplying energy to the sector (Egli, 2014).
Lightning strikes also pose a threat to transmitters (Engineering the Future, 2011).

\section{Spatial patterns}

The exposure of ICT structures to weather-related damage and disruption depends on their location (Neumayer et al., 2011). Infrastructure such as above-ground cables and transmitters located in the south of the UK will be more exposed to higher temperatures than in the north, because of spatial pattern of climate change (Murphy et al., 2009). While individual structures may be locally exposed to increasing risks from precipitation, flooding, heatwaves and storms, the wide spatial distribution and inherent interconnectivity of ICTs helps to ensure that the network at the national level is robust. Very few impacts are likely to affect the entire national ICT network, and those that do are related to probably minor changes in the quality of signal resulting from temperature effects on radio-frequency transmission (Horrocks et al., 2010).

At the local level, however, the impact of extreme weather is more significant, particularly in rural areas, locations at the end of a network line or areas served by only one or two networks. Mast sharing in remoter and rural areas may increase vulnerability due to the dependence of the local network on only one structure. From the perspective of individual businesses, climate change 
may therefore pose some additional pressure. Such risks are more significant for smaller businesses and remote workers (Defra, 2012)

\section{Indirect impacts and risks}

Indirect impacts on ICTs can arise from climate-related disruption to provision of critical ICT materials and resources within the UK. The occurrence of extreme weather events can prevent staff from either reaching their normal place of work or attending sites to repair or restore failed components of the infrastructure (such as base stations, antennae and exchanges), extending downtime. Extreme weather events can also generate an increased use (transmission volumes) of the ICT infrastructure as greater numbers work from home or otherwise at a distance from their normal place of work. This increases the demand for reliable and resilient ICT networks.

\section{Global interdependence}

The impacts of climate change will also be felt around the world, with different risks likely to be significant in different regions in the very near term, according to the IPCC (2014). With networks and services depend increasingly on international partners, suppliers, materials and, to some extent, skills and expertise (Adams et al., 2014), the effects of climate change around the world provide a further source of indirect impacts on the UK's ICTs.

This international interdependence extends not only to the global supply chains supporting provision of materials and devices but also to the hosting, storage and transmission of data. For example many online and telephone services critical to business and leisure in the UK are hosted at data or call centres physically located outside the UK. Rising sea levels and extreme weather events may affect the operation of data centres and service centres in low-lying areas, such as the Netherlands, and vulnerable areas in the subcontinent of India. Raw materials (such as pine for telegraph poles and rare or precious metals) and components are sourced from or manufactured in different countries and may face increasing climate impacts on their production and transport. Supporting architectures and infrastructure, such as fibre-optic networks, are routed across the world and are potentially vulnerable to a wider range of climate impacts (Munich RE, 2012).

\section{Risk from cross-sectoral interdependencies}

The UK's NI and wider economy are heavily reliant on ICT networks and services for their continued daily operation. For example ICTs provide a critical operational service for much of the UK transport infrastructure, from road information on the motorway network to air traffic control. ICTs also provide a critical operational service for much of the UK energy infrastructure, both at individual plants and across networks, where it supports supply and demand forecasting and rerouting of gas and electricity supplies through the transmission and distribution networks. Listed in Table 2 are the key dependencies on ICTs identified in the expert workshop. The criticality of

\begin{tabular}{ll} 
Category & \multicolumn{1}{c}{ Dependence on ICTs } \\
\hline Business as usual & Customer transactions (including \\
& electronic banking) \\
& Staff-to-staff communication (e-mail, \\
& phone call, videoconferencing) \\
& Financial management \\
& E-commerce \\
& Ticketing and billing systems \\
& Customer/passenger information systems \\
& Healthcare provision \\
& Automated teller machines \\
& Traffic signalling \\
& Traffic management \\
& Navigation (waterborne, satellite- and \\
& land-based) \\
& Vehicles - road and rail \\
& Aircraft and marine vessels \\
& Rail signalling \\
& Air traffic management \\
& Supply chain management \\
Incident & Logistics (despatch and delivery of goods) \\
management & Real-time delivery management and \\
& reporting \\
& Supervisory control and data acquisition \\
& Remote management of pumps and \\
& switches in network \\
& Water distribution \\
& Energy generation and distribution (in \\
& particular nuclear and smart grids) \\
& ICT network management \\
& Policing, fire and rescue, ambulance (air \\
& wave) \\
& Transport delay rectification \\
& Natural emergencies \\
& Man-made emergencies \\
\hline & \\
& \\
&
\end{tabular}

Source: Horrocks et al. (2010)

Table 2. Critical dependencies on ICT

ICTs implied that any disruption to ICT service provision can have knock-on effects and in extreme cases has the potential to result in multisectoral 'cascade failures'. Resilience in the ICT systems as a whole is therefore critical to the continued operation of the other sectors (Defra, 2012; Parandehgheibi et al., 2014).

On the other hand, the ICT sector has a relatively low dependency on other sectors for its continuing operation, but is completely dependent on energy (AEA, 2009). Any climate-related disruption to critical energy supplies has the potential to cause multiple and wide-ranging impacts on ICT networks. For example, high temperatures during summer could increase the demand for 
energy for the cooling of buildings, including data centres, while also affecting energy infrastructure such as through the derating of power lines. Increased humidity may also lead to increased degradation of energy equipment and infrastructure (McColl et al., 2012). With increased codependence of power and data on the same lines, this is a further risk for ICTs.

Unfortunately, the fragmentation of delivery and governance of the UK NI means that "no-one has any responsibility or accountability for looking across the NI as a whole, i.e. across the network of networks' and 'there is little or no knowledge of vulnerabilities and risk arising from interdependencies across the NI which means that investment in adequate resilience will always be low priority' (CST, 2009). The problems have attracted a few research studies to investigate and quantify the risks incurred from cross-sectoral interdependencies. For example Buldyrev et al. (2010) highlighted the cascading failure risks of a coupled ICT and energy system in Italy. Fu et al. $(2012,2014)$ showed that internetwork dependencies can lead to geographically unconstrained failure and varying the nature of cross-network dependency can modify the behaviour of an interdependent system and, hence, change the conditions for its safe operation (Figure 1).

\section{Management of climate change impacts and risks}

In this section, the four main areas for managing climate change impacts and risks are characterised, and some opportunities presented to the ICT sector due to climate change are identified.

\section{Physical structures and networks}

While there is inherent resilience available from the multiple networks that make up ICTs, there is potential for resilience to be enhanced to cope with localised extreme weather hazards (Agarwal et al., 2015). The diversity of systems and their interoperability must be maintained or improved to ensure a level

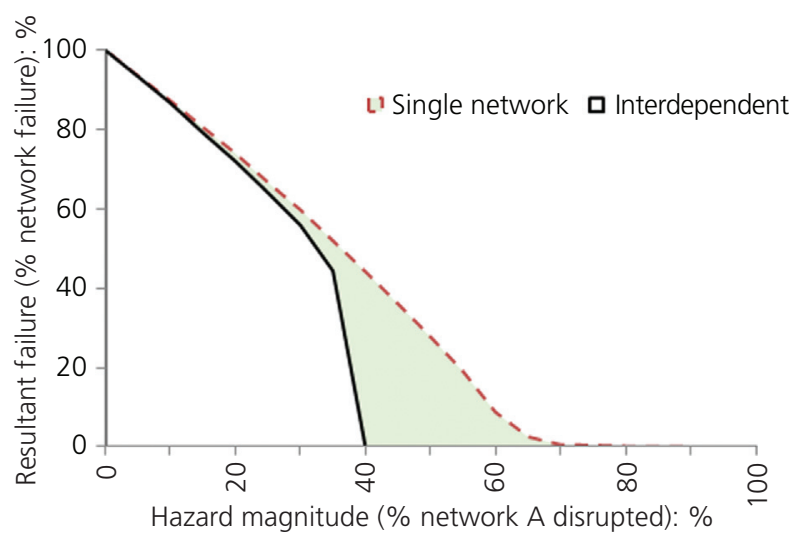

Figure 1. Performance comparison of a single and an interdependent network (updated from Fu et al., 2012). The performance is measured here in terms of remaining largest network component of redundancy sufficient to deal with local events that may rapidly put pressure on, for example, mobile networks at times of crisis.

The most exposed and/or sensitive ICT structures can be addressed through improvements in spatial planning and environmentally appropriate design, just as in any other sector. For areas and locations that do not receive a wide range of alternative network coverage, further strategic or dynamic nodes could be introduced for specific locations where interconnectivity needs to be allowed under disaster conditions, balanced against a cost-benefit analysis (Minh et al., 2014).

\section{New technology}

The modular approach to ICT infrastructure design, coupled with a rapid refresh cycle, facilitates incremental adaptation, allowing progressively more climate-resilient components to be integrated. With respect to devices, there would be only limited benefit from revising technical standards or product specifications as a precautionary response to climate change. In most cases (satellite systems being a significant exception), the product life is short relative to climate change. Product designs (and accompanying standards) can be expected to 'evolve' in new generations of devices, in response to a range of drivers, including experiences of weather events. The pace of technological change in the ICT sector enables this flexibility, but to maximise the potential for adaptation, greater climate awareness in the research and development parts of the sector may be required.

Whole trends in the sector may be tuned for climate adaptation benefits. Advances in cloud computing provide unique opportunities for enhancing resilience (Harter et al., 2014; Souza Couto et al., 2014) by, for example, enabling computational load to be transferred from site to site around the globe, to avoid areas of increased local weather risk, but this will depend on good early warnings and even higher maintenance of connectivity with end users.

\section{Handling interdependencies}

Resilience in other sectors dependent on ICTs would be improved through increased awareness of the potential risks to ICT structures and networks and increased collaboration and engagement around specific issues (Parandehgheibi et al., 2014). Conversely, ICT companies are generally well practised at managing risk in their own sector, but may be less effective at considering the implications of risks in related sectors (e.g. failures in the energy sector that affect the ICT sector and extreme weather impacts on road that affect maintenance and repair of telecommunications infrastructure). There is a role for a knowledgeable ICT sector to enable the analysis and management of climate risk throughout service supply chains and to educate customers about the potential risks and opportunities that a changing climate might present (Eakin et al., 2015; Kelly and Adolph, 2008; Upadhyay and Bijalwan, 2015).

Procurement procedures could be used to demand an improved level of climate resilience, which emphasises continuity of service 
Infrastructure Asset Management

Volume 3 Issue 1
Exploring impacts of climate change on

UK's ICT infrastructure

Fu, Horrocks and Winne rather than compensation for disruption. Organisational protocols for system backup and information security (such as business continuity standards) already exist and can provide resilience for both providers and consumers of ICTs against disruption from climate events.

\section{Contingency planning and responding to extreme weather events}

The current approach to dealing with weather disruption seems to be to accept that the risk will occur and then respond to its consequences, rather than to be proactive and to reduce or avoid the risk occurring. With increasingly severe and frequent extreme weather, this may become expensive and unsatisfactory (Mukherjee et al., 2014). More comprehensive contingency planning for a range of climate hazards and responses could be supported by wider use of weather event early-warning systems, linking infrastructure providers and operators directly with the Met Office and the Environment Agency (for flood, storm and heat warnings). Better collaboration with local authorities may help to ensure a more efficient and effective recovery phase after a weather disruption. Good practice in business continuity should ensure that organisations can develop suitable contingency arrangements for weather-related extreme events (alongside plans for other natural disasters and terrorism incidents). Arrangements may include access to emergency power and backup data centres.

\section{Opportunities}

The increased risk of climate extremes presents an opportunity for developing rapid deployment business for ICT firms that can offer support during disasters. ICT has an important role to play in implementing climate-related responses and adaptive practices (Eakin et al., 2015; Kelly and Adolph, 2008; Upadhyay and Bijalwan, 2015). For example there is likely to be growth of demand for products and services to minimise business disruption through business recovery and continuity. Increased demand is expected for solutions that help customers understand and protect themselves from physical risks of climate change while maintaining and enhancing communications capability. The development and provision of equipment and services to measure, monitor, mitigate and respond to climate change impacts, such as increased satellite monitoring, and to provide emergency and disaster warnings is expected.

ICT could have a truly significant effect on reducing the use of energy and thus greenhouse-gas emissions in changing climate. For example, ICT in the form of videoconferencing eliminates the need for travel, and intelligent transport (based on vehicles, roads and traffic control centres equipped with ICTs) can not only improve safety but also cut the use of fuel. And when it comes to electricity supplies, by avoiding wastage and making distribution more efficient, smart grids could reduce demand substantially.

\section{Barriers to adaptation}

A number of challenges and barriers to adaptation in ICTs have been identified. These include the following.
Low awareness of climate change risk: The ICT industry is well practised at managing risk in their own sector. More is required to consider the implications of risks in related sectors and to manage risks throughout service supply chains.

- Current business model: The ICT infrastructure is designed to offer the resilience to cope with the normal spread of weather events. There is a need to shift the balance of investment towards systems that are resilient to future range of climate conditions.

- Business case for action on climate risk: There is a lack of certainty surrounding the magnitude and likelihood of potential climate change impacts. The evidence base that assesses recent experiences of weather events in the sector is limited. There is therefore an underdeveloped 'business case' for providers to invest in enhancing climate resilience.

- Ownership and sharing: There is an increasing trend towards sharing of elements of the infrastructure by several service providers. This sharing needs to become fully transparent to service users such that they understand their risks and, hence, take individual mitigation action and spread their risks.

- Scale effects: The current approach to strengthening resilience has focused on regional resilience. The increasing virtual nature of ICT services means that many critical ICTs may be physically located outside the UK and, hence, may be more difficult to protect.

\section{Conclusions and discussion}

The ICT sector continues to grow and evolve rapidly. Given the pace of development and change in ICT, new risks or solutions can emerge relatively quickly, and additional skills and capabilities will be needed in order to enhance climate resilience of ICT infrastructure. This paper synthesises the current research and practice in the sector to address the gap in knowledge relating to climate change and its potential impacts on the ICT sector. This study found that the UK's ICT sector is inherently resilient to climate impacts. Providers and consumers of ICTs will nevertheless need to consider adaptation, because of the UK's increasing dependence on ICTs and increases in extreme weather events. This study reveals that ICTs are vulnerable to a number of current and future climate risks, and climate impacts on ICTs can have considerable crosssectoral implications for infrastructure and business.

This study has identified a number of key areas for further research and development, including the following.

- A more detailed follow-up assessment of the climate change risks presented in this paper, including an objective prioritisation and identification of the actors responsible for each risk. This would enable more concrete identification of the role that the government will need to play in improving climate resilience in the ICT sector.

- A review of evidence of the impact of past weather events on ICT infrastructure. This would start to strengthen the business case for action on adaptation. 
Infrastructure Asset Management

Volume 3 Issue 1
Exploring impacts of climate change on

UK's ICT infrastructure

Fu, Horrocks and Winne
- Further research into how absolute humidity may change under climate projections (as this is relevant to optimising the environmental conditions for IT devices) and examining potential changes in wireless signal based on temperature and rain rates in the UK Climate Projections.

- Spatial analysis of ICT climate vulnerabilities across the UK, focusing on the identification of critical nodes vulnerable to climate hazard damage.

- Distributional analysis of potential climate impacts on ICTs (who suffers most and who pays for greater resilience).

- Vulnerability of ICT networks and supply chains outside the UK, The full range of international climate risks associated with the offshoring of data and applications needs research and evaluation.

- Systems-based research, in conjunction with other NI sectors, to understand the acknowledged interdependencies, and how best to manage weather risks that can lead to cascade failures.

Alongside these, further policy-oriented research would be welcome. There is a wide range of policy options that could be considered to incentivise adaptation in ICT (including support for innovation in research, funding for demonstration projects, public sector co-investment in adaptation measures, measures to embed climate risk in the current market and regulatory incentives). Scoping and appraisal of these options is needed. A policy study to review the potential role of government, the regulators and existing market structures in addressing climate risks in the ICT sector may be helpful.

\section{Acknowledgements}

This paper is based on the work done for the Living with Environmental Change Infrastructure Report Card commissioned by the Natural Environment Research Council and the Environment Agency. Gaihua Fu is funded under an Engineering and Physical Sciences Research Council (EPSRC) Resilient Networks (RESNET) project (EP/I035781/1).

\section{REFERENCES}

Adams P, Steeves J, Ashe B, Firth J and Rabb R (2014) Climate

Risks Study for Telecommunications and Data Center Services. Acclimatise, Newark, UK. See http://www.acclimatise.uk.com/ login/uploaded/resources/GSA\%20Climate\%20Risks\%20Study $\% 20$ for $\% 20$ Telecommunications $\% 20$ and $\% 20$ Data $\% 20$ Center $\%$ 20Services\%20-\%20FINAL\%20October\%202014.pdf (accessed 18/01/2015).

AEA (Atomic Energy Authority) (2009) An Overview of Systemic Interdependencies of the UK National Infrastructure: Report to the Chief Scientific Advisor of DfT and BIS. AEA, Harwell, Didcot, Oxfordshire, UK.

Agarwal PK, Efrat A, Ganjugunte SK et al. (2015) The resilience of WDM networks to probabilistic geographical failures. IEEE/ACM Transactions on Networking 21(5): 1525-1538, http://dx.doi.org/10.1109/INFCOM.2011.5934942.

Bacon D (2012) Modelling Rain Rate Maps for Fixed-Link Frequency Assignment Procedures. Office of Communications
(Ofcom), London, UK, Ofcom contract number 796.

See http://stakeholders.ofcom.org.uk/binaries/research/ technology-research/2012-2013/RainRateFinal.pdf (accessed 21/01/2015).

Baglee A, Haworth A and Anastasi S (2012) Climate Change Risk Assessment for the Business, Industry and Services Sector, UK 2012 Climate Change Risk Assessment. Department for Environment, Food and Rural Affairs (Defra), London, UK, Defra contract number GA0204.

Buldyrev S, Parshani R, Paul G, Stanley H and Havlin S (2010) Catastrophic cascade of failures in interdependent networks. Nature 464(7291): 1025-1028, http://dx.doi.org/10.1038/ nature08932.

Carbon Disclosure Project (2012) Insights into Climate Change Adaptation by UK Companies. Defra, London, UK. See http://archive.defra.gov.uk/environment/climate/ documents/cdp-adaptationreport.pdf (accessed 01/08/2014).

Chołda P, Mykkeltveit A, Helvik BE, Wittner OJ and Jajszczyk A (2007) A survey of resilience differentiation frameworks in communication networks. IEEE Communications Surveys \& Tutorials 9(4): 32-55, http://dx.doi.org/10.1109/COMST.2007. 4444749 .

Clemente D (2013) Cyber Security and Global Interdependence: What Is Critical? Report for the Royal Institute of International Affairs. Chatham House, London, UK. See http://www.chathamhouse.org/sites/files/chathamhouse/public/ Research/International\%20Security/0213pr_cyber.pdf (accessed 21/01/2015).

CST (Council for Science and Technology) (2009) A National Infrastructure for the 21st Century. CST, London, UK. See http://www.cst.gov.uk/reports/files/national-infrastructurereport.pdf (accessed 19/01/2015).

Defra (Department for Environment, Food and Rural Affairs) (2009) Engineering, Infrastructure and Climate Change Adaptation Conference, Engineering to ensure long-term climate resilient infrastructure. Report of Proceedings. Defra, London, UK.

Defra (2012) The CCRA Evidence Report: UK 2012 Climate Change Risk Assessment, by HR Wallingford Ltd, AMEC Environment \& Infrastructure UK, the Met Office, Collingwood Environment Planning, Alexander Ballard Ltd, Paul Watkiss. Her Majesty's Stationery Office, London, UK, Defra report number D.4.2.1.

Defra (2013) The National Adaptation Programme: Making the Country Resilient to a Changing Climate. Defra, London, UK.

Egli D (2014) Beyond the Storms: Strengthening Homeland Security and Disaster Management. Routledge, London, UK. Engineering the Future (2011) Infrastructure, Engineering and Climate Change Adaptation - Ensuring Services in an Uncertain Future. The Royal Academy of Engineering, London, UK.

Eakin H, Wightman P, Hsu D et al. (2015) Information and communication technologies and climate change adaptation in Latin America and the Caribbean: a framework for action. 
Infrastructure Asset Management

Volume 3 Issue 1
Exploring impacts of climate change on

UK's ICT infrastructure

Fu, Horrocks and Winne
Climate and Development 7(3): 208-222, http://dx.doi.org/ 10.1080/17565529.2014.951021.

Fu G, Khoury M, Dawson D and Bullock S (2012) Vulnerability Analysis of Interdependent Infrastructure Systems. In Proceedings of the European Conference on Complex Systems 2012. Springer International Publishing, Switzerland, pp. 317-323.

Fu G, Dawson D, Khoury M and Bullock S (2014) Interdependent networks: vulnerability analysis and strategies to limit cascading failure. European Physical Journal B 87(7): 1-10, http://dx.doi.org/10.1140/epjb/e2014-40876-y.

Harter I, Hoffmann M, Schupke D and Carle G (2014) Scalable resilient virtual network design algorithms for cloud services. Proceedings of the 6th International Workshop on Reliable Networks Design and Modeling, pp. 123-130.

Horrocks L, Beckford J, Hodgson N et al. (2010) Adapting the ICT Sector to the Impacts of Climate Change - Final Report. Defra, London, UK, Defra contract number RMP 5604.

IPCC (Intergovernmental Panel on Climate Change) (2014) Summary for policy makers. Climate Change 2014: Impacts, Adaptation and Vulnerability, Contribution of Working Group II to the Fifth Assessment Report of the Intergovernmental Panel on Climate Change. IPCC, Geneva, Switzerland. See http://ipcc-wg2.gov/AR5/images/uploads/IPCC_WG2AR5 SPM_Approved.pdf (accessed 11/01/2015).

ITU (International Telecommunication Union) (2014) ICT Facts and Figure. ITU, Geneva, Switzerland. See http://www.itu.int/ en/ITU-D/Statistics/Documents/facts/ICTFactsFigures2014-e. pdf (accessed 31/01/2015).

Jacob K, Maxemchuk N, Deodatis G et al. (2011)

Telecommunications. In Responding to Climate Change in New York State: The ClimAID Integrated Assessment for Effective Climate Change Adaptation: Technical Report (Rosenzweig C, Solecki W, DeGaetano A et al. (eds)). New York State Energy Research and Development Authority, New York, NY, USA, pp. 363-396.

Jenkins GJ, Perry MC and Prior MJ (2009) The Climate of the United Kingdom and Recent Trends, revised edn. Met Office Hadley Centre, Exeter, UK.

Kelly T and Adolph M (2008) ITU-T initiatives on climate change. IEEE Communications Magazine 46(10): 108-114, http://dx.doi.org/10.1109/MCOM.2008.4644127.

Maunsell Australian Pty Ltd (2008) Impact of Climate Change on Australia's Telecommunications, Infrastructure. Garnaut Climate Change Review report, Melbourne, Australia. See http://www.garnautreview.org.au/CA25734E0016A131/ WebObj/02-CTelecommunications/\$File/02-C\% 20Telecommunications.pdf (accessed 18/01/2015).

McColl L, Agelina T and Betts R (2012) Climate Change Risk Assessment for the Energy Sector, UK 2012 Climate Change Risk Assessment. Defra, London, UK, Defra contract number GA0204.

Minh Q, Nguyen K, Borcea C and Yamada S (2014) On-the-fly establishment of multihop wireless access networks for disaster recovery. IEEE Communications Magazine 52(10): 60-66, http://dx.doi.org/10.1109/MCOM.2014.6917403.
Mishra R, Keimasi M and Das D (2004) The temperature ratings of electronic parts. Electronics Cooling 10(1): 20-29.

Mukherjee B, Habib M and Dikbiyik F (2014) Network adaptability from disaster disruptions and cascading failures. IEEE Communications Magazine 52(5): 230-238, http://dx.doi.org/10.1109/MCOM.2014.6815917.

Munich RE (2012) Topics Geo: Natural Catastrophes 2011: Analyses, Assessments, Positions. Munich RE, Munich, Germany. See http://risk.earthmind.net/files/MunichRe-2012Natural-Catastrophes-2011.pdf (accessed 02/02/2015).

Murphy JM, Sexton DMH, Jenkins GJ et al. (2009) UK Climate Projections Science Report: Climate Change Projections. Met Office Hadley Centre, Exeter, UK.

Neumayer S, Zussman G, Cohen R and Modiano E (2011) Assessing the vulnerability of the fiber infrastructure to disasters. IEEE/ACM Transactions on Networking 19(6): 1610-1623, http://dx.doi.org/10.1109/TNET.2011.2128879.

Nogueira M, Choda P, Medhi D and Doverspike R (2014) Disaster resilience in communication networks. IEEE Communications Magazine 52(10): 44-45, http://dx.doi.org/10.1109/MCOM. 2014.6917400.

Ofcom (Office of Communications) (2014) Ofcom Facts and Figures. Ofcom, London, UK. See http://media.ofcom.org.uk/ facts/ (accessed 31/01/2015).

Ospina AV and Heeks R (2010) Unveiling the Links between ICTS \& Climate Change in Developing Countries: A Scoping Study. Centre for Development Informatics, Institute for Development Policy and Planning, University of Manchester, Manchester, UK. See http://www.niccd.org/ScopingStudy.pdf (accessed 18/12/2015).

Ospina AV, Faulkner D and Dickerson K (2014) Resilient Pathways: the Adaptation of the ICT Sector to Climate Change. TU, Geneva, Switzerland, TU report. See http://www. itu.int/en/ITU-T/climatechange/Documents/Publications/ Resilient_Pathways-E.PDF (accessed 21/12/2015).

Parandehgheibi M, Modiano E and Hay D (2014) Mitigating cascading failures in interdependent power grids and communication networks. In Proceedings of 2014 IEEE International Conference on Smart Grid Communications. Institute of Electrical and Electronics Engineers (IEEE), Piscataway, NJ, USA, pp. 242-247.

Paulson KS (2010) Trends in the incidence of rain rates associated with outages on fixed links operating above $10 \mathrm{GHz}$ in the southern United Kingdom. Radio Science 45(1): RS1011, http://dx.doi.org/10.1029/2009RS004193.

Paulson KS (2011) The effects of climate change on microwave telecommunication. In Proceedings of the 11th International Conference on Telecommunication (ConTel), Graz, Austria. IEEE, Piscataway, NJ, USA, pp. 157-160.

Paulson KS and Al-Mreri A (2011) Trends in the incidence of rain height and the effects on global satellite telecommunications. IET Microwaves, Antennas \& Propagation 5(14): 1710-1713, http://dx.doi.org/10.1049/iet-map.2010.0507.

Rak J (2015) Resilient Routing in Communication Networks. Springer, C, Switzerland. 
Souza Couto R, Secci S, Mitre Campista M and Kosmalski Costa L (2014) Network design requirements for disaster resilience in IaaS clouds. IEEE Communications Magazine 52(10): 52-58, http://dx.doi.org/10.1109/MCOM.2014.6917402.

Steeves J and Surminski S (2014) Taking an Organisational Approach to Private Sector Adaptation - the Case of Tata Teleservices in India. Centre for Climate Change Economics and Policy, Leeds, UK and Grantham Research Institute on Climate Change and the Environment, London, UK, working paper. See http://www.lse.ac.uk/GranthamInstitute/wp-content/ uploads/2014/11/Working-Paper-171-Steeves-and-Surminski2014.pdf (accessed 21/01/2015).

Sterbenz J, Hutchison D, Cetinkaya E et al. (2010) Resilience and survivability in communication networks: strategies, principles, and survey of disciplines. Computer Network 54(8): 1245-1265, http://dx.doi.org/10.1016/j.comnet.2010. 03.005 .

Sterbenz J, Cetinkaya E, Hameed M et al. (2013) Evaluation of network resilience, survivability, and disruption tolerance: analysis, topology generation, simulation and experimentation. Telecommunication Systems 52(2): 705-736, http://dx.doi.org/ 10.1007/s11235-011-9573-6.

UK Trade \& Investment (2014) Information Communications Technology (ICT) in the UK: Investment Opportunities. UK Trade \& Investment, London, UK. See https://www.gov.uk/ government/publications/information-communicationstechnology-ict-in-the-uk-investment-opportunities/informationcommunications-technology-ict-in-the-uk-investmentopportunities\#overview (accessed 28/01/2015).

Upadhyay A and Bijalwan A (2015) Climate change adaptation: services and role of information communication technology (ICT) in India. American Journal of Environmental Protection 4(1): 70-74, http://dx.doi.org/10.11648/j.ajep.20150401.20. Wong J and Schuchard R (2011) Adapting to Climate Change: a Guide for the ICT Industry. BSR Industry Series, San Francisco, BSR. See http://www.bsr.org/reports/ BSR_Climate_Change_Adaptation_ICT.pdf (accessed 25/01/2015).

\section{WHAT DO YOU THINK?}

To discuss this paper, please submit up to 500 words to the editor at journals@ice.org.uk. Your contribution will be forwarded to the author(s) for a reply and, if considered appropriate by the editorial panel, will be published as a discussion in a future issue of the journal. 